\title{
Computer Science is not Enough
}

\author{
John K. Bennett* and S. Revi Sterling ${ }^{* *}$ \\ *jkb@colorado.edu, ATLAS Institute, University of Colorado at Boulder, USA \\ ** revi.sterling@colorado.edu , ATLAS Institute, University of Colorado at Boulder, USA
}

\begin{abstract}
Despite huge investment, and the best of intentions, most development projects fail. This is particularly true of Information and Communication Technology for Development (ICTD) projects. We contend that a significant contributor to this failure is the lack of breadth in project design and implementation, and in the training of project implementers. Successful ICTD interventions, in addition to being based on the best computer science research has to offer, must be guided by the relevant social, cultural, political, economic and gender factors that underlie the interaction of the technology with the community into which it is being placed. We therefore argue that efforts to distance computer science from the broader context of ICTD scholarship and practice are misguided. ICTD should be recognized as a truly interdisciplinary area of research and practice. We further argue that ICTD as a discipline has a particular need for academic practitioners. We close with a compilation of current known ICTD academic efforts worldwide.
\end{abstract}

Keywords: Information and Communication Technology for Development

Acknowledgement: The authors acknowledge the work of another tripleC effort - the Computing Community Consortium an effort of the Computing Research Association, and their efforts to define technology's role in Global Development.

There are several active debates within the ICTD active community - is ICTD becoming a standalone subject? If it remains a sub-discipline, under what department(s) should it live? These arguments, however, are secondary to the more important question - are we doing ICT for Development, or ICT and Development? We push for the primacy of the former, as the intent of ICTD is actively to promote human and community development.

\section{Computer Science and ICTD}

\subsection{The Digital Divide}

The majority of the world's population does not have adequate access to information or communication. Roughly 2.5 billion people in the Global South live on less than two dollars a day (Collins, Morduch, Rutherfod and Ruthven, 2009). Among this group, several countries have less than $1 \%$ internet penetration (ITU, 2009). Illiteracy, lack of education and training, lack of power and communication infrastructure, and higher priority community development objectives combine to limit the effectiveness of efforts to introduce information and communication technology (ICT)-based development solutions. People in developing communities usually cannot benefit from the introduction of telemedicine, distance education, e-government, and other sophisticated Internet and technology-based strategies that are prevalent in the developed world.

\subsection{The Need for Breadth}

Despite billions of dollars invested with the best of intentions, there is a demonstrable lack of success in achieving global and local development objectives. This is particularly true of Information and Communication Technology for Development (ICTD) efforts. We contend that a significant contributor to this failure is the lack of breadth in both the implementation of development, and in the training of those who practice development. Those who work in development tend to communicate only with those most aligned with their field. For example, food security experts rarely attend community informatics conferences; health experts rarely attend ICTD conferences. Even re- 
searchers and practitioners within the same community rarely cross paths (especially when there are significant geographical distances between them), and journals go unread by the communities who have contributed to the findings reported therein, who are therefore unable to put the recommended outcomes into action. It is little wonder that the needle barely moves in the overall progress of under-developed communities.

Many of these concerns have been articulated in the three ACM/IEEE ICTD conferences to date. However, while attendance at this conference is continues to grow, many of the presenters and attendees are the same from year to year - a predominantly computer science-oriented group of researchers and practitioners who themselves bemoan the disconnect in ICTD between the "ICT" and the "D." This separation is largely the result of both legacy and timing. Development studies has been an area of scholarship and practice for over 60 years; mass communications departments have been working in ICTD (although it is called development communications in this space) since the 1960s. Computer science is late to the game - yet often does not adequately acknowledge or build upon development's historical foundations. The underlying view that computer scientists will save the world because other development sectors have not yet been successful in doing so is naïve and overlooks the complexities of real-world development.

Information and Communication Technology is a critical component in global change strategies, but it needs to be considered as a component of development rather than as a stand-alone development sector. The eight UN Millennium Development Goals (none of which list ICTD access, use and capacity building as top goals) have encouraged numerous articles about the transformative role that ICT can and should play in attaining these goals (Gerster and Zimmerman, 2005; InfoDev, 2006). While the MDGs perhaps can be criticized for their normative approach to global iniquities, they have galvanized and coordinated efforts across industry, academia, practitioners, multilateral agencies and foundations, and NGOs. ICTD, especially the ICTD efforts grounded in computer Science, would do well to be as inclusive and cohesive.

\subsection{ICT for Development vs. ICT and Development}

Mainstream computer science research has the potential to drive ICTD innovation, while at the same time contributing to mainstream "First World" research and development efforts. There are few limits to the hardware and software systems that computer science can bring to bear upon the seemingly-limitless problems that result from sustained community and regional underdevelopment. The current approach - creating technologies based primarily upon our understanding and standpoint - perpetuates a model of ICT and Development, where we are technical experts whose talents can be used in development interventions. In contrast, creating technologies that have the potential to catalyze social change, and mapping human needs to technologies that directly respond to specific development problems represents ICT for Development.

In a time of stagnant or declining enrolments matched with anxiety myths about the health of the technology sector, ICTD is a natural draw for students and faculty who aspire to greater impact. Yet, academic instruction and research in ICTD is limited to the extent that interdisciplinary lineages exist and support ICTD done "right." There is a critical need to develop institutional infrastructure and funding support models for the academician who is $50 \%$ computer science; $25 \%$ mass communication, information systems and sociology; and $25 \%$ development studies. This need is not unique to computer science departments; social science and humanities programs that have traditionally been the home of graduate development students cannot remain effective without the ability to leverage the power and near-ubiquity of modern ICT. The list of known academic ICTD efforts, listed in the Appendix, demonstrates the breadth of ICTD topics and home departments representative of this interrelated field. Master's program designed to offer a holistic education in the interrelated nature of development do exist - there are programs at the University of Manchester (UK), Universidad Rey Juan Carlos, University of Stockholm, University of Salzburg, and a joint academic program between the Hasso Plattner Institute and University of Capetown. However, the fear of the interdisciplinary disciplinary field pervades - how can we ensure sufficient 
depth in the presence of breadth? This argument is not new - interdisciplinary research and education programs routinely face such questions, despite demonstrated funding and research success.

Universities tend to be conservative when it comes to organizational structure. Even as we argue against academic silos, we fight to preserve the purity and primacy of our historic intellectual turf. This contradiction is emblematic of the need cross-cutting academic programs that can focus the intellectual breadth of the entire campus upon ICTD education and research, and in which faculty (especially junior faculty) are rewarded for applying their domain proficiency in larger context of development.

\section{The Need for Academic Practitioners}

Universities have long enjoyed a reputation for advancing learning through service, although the reality is that many such efforts contribute to a schism between research and praxis. Given the potential for ICTD to support a rich assortment of development strategies, universities need to graduate experts who can help bridge the gap between the advantages of the networked information society, and those with the greatest potential to benefit if issues of access, social equity, sustainability, and appropriate design and distribution are addressed. However, the focus has to remain on people - if ICTD experts are not focused on actually serving human need, it's not development.

As a research area, ICTD is just now emerging as a clearly identifiable focus - there are perhaps a half dozen respected ICTD journals, and the premier conference in the field is less than four years old. A 2010 report shows that the field is growing, with several hundred academic researchers and several thousand graduate students working in some aspect of ICTD (Heeks, 2010). Although ICTD is emerging as a formal discipline at several of universities internationally, only a few programs related to ICTD exist in the United States. These programs primarily cater to the doctoral student, although there is a trend towards master's level programs, including ICTD certificate curricula and the announcement of two Master's degrees in ICTD to bring the total "practitioner" programs worldwide to six - of which five are in the European Union. Of the 100 ICTD courses taught at Universities worldwide, only $20 \%$ are taught in computer science departments.

If computer science is late to the game, American universities are also overdue in recognizing the value of the ICTD academic practitioner as a driving force for effective ICTD development and deployment, whose efforts will in turn sustain ICTD research and scholarship.

More than ever, we need to develop and support programs that represent a commitment to challenge both the academic silos and chasms in development that serve to perpetuate the inequities of underdevelopment. ICTD academic programs need to build on existing on-campus expertise and strength in many of the core areas that define the discipline, which will provide a focal point for both practice and research. The interdisciplinary nature of ICTD demands us to create interdisciplinary programs that make people more capable learners, more innovative teachers, more creative thinkers, more effective leaders and more engaged global citizens.

Instead of the focus on short-term research projects and discussions about tenure in ICTD, programs would be better served to train academic practitioners to strategically and efficiently utilize technology to help facilitate health, education, civil service and poverty alleviation initiatives all over the world, as well as to connect these efforts to amplify their impact. To this end, students will need to both specialize in the technical and social aspects of ICT while acquiring a broad foundation in development studies, public health, social sciences and assessment methods, in order to make a positive difference in the complex and interrelated systems of community and economic development. In order for ICT-based development interventions to succeed, technological considerations must be balanced with social, cultural, political, gender and other issues not related to the chosen technology. Only when students are channelling human needs into technical solutions, we can say that we are "doing" development. 
Appendix: Known ICTD Courses

\begin{tabular}{|c|c|c|c|}
\hline Institution & Course Title & Level & Home Department \\
\hline $\begin{array}{l}\text { Agder University \& } \\
\text { Mzumbe University }\end{array}$ & ICT in Development & $\mathrm{G}(\mathrm{grad})$ & \\
\hline American University & Nations, Policy \& Information Technology & G & Kogod School of Business \\
\hline BRAC University & Development Informatics & G & Development Studies \\
\hline Butler University & International Communications Systems & $\begin{array}{l}\text { U (under- } \\
\text { grad) }\end{array}$ & Journalism \\
\hline CalTech & Product Design for the Developing World & $U$ & \\
\hline $\begin{array}{l}\text { Carnegie Mellon Uni- } \\
\text { versity }\end{array}$ & $\begin{array}{l}\text { Human-Computer Interaction in the Develop- } \\
\text { ing World }\end{array}$ & G & School of Computer Science \\
\hline $\begin{array}{l}\text { Carnegie Mellon Uni- } \\
\text { versity }\end{array}$ & Technology and Global Development & & School of Computer Science \\
\hline $\begin{array}{l}\text { Carnegie Mellon Uni- } \\
\text { versity }\end{array}$ & $\begin{array}{l}\text { iSTEP: Technology Field Research in De- } \\
\text { veloping Communities }\end{array}$ & & School of Computer Science \\
\hline $\begin{array}{l}\text { Carnegie Mellon Uni- } \\
\text { versity }\end{array}$ & Technology for Developing Communities & & School of Computer Science \\
\hline $\begin{array}{l}\text { Carnegie Mellon Uni- } \\
\text { versity }\end{array}$ & Technology and Global Development & $\mathrm{U}$ & School of Computer Science \\
\hline $\begin{array}{l}\text { Carnegie Mellon Uni- } \\
\text { versity }\end{array}$ & $\begin{array}{l}\text { Technology and Policy for Disaster and } \\
\text { Humanitarian Response }\end{array}$ & G & School of Computer Science \\
\hline $\begin{array}{l}\text { Colorado State Uni- } \\
\text { versity }\end{array}$ & $\begin{array}{l}\text { Technology in Community-Based Develop- } \\
\text { ment }\end{array}$ & G & $\begin{array}{l}\text { Intl Institute for Sustainable } \\
\text { Development }\end{array}$ \\
\hline $\begin{array}{l}\text { Copenhagen Business } \\
\text { School }\end{array}$ & IT, Institutions and Development & & \\
\hline Dominican University & Community Informatics & G & Library and Information Science \\
\hline $\begin{array}{l}\text { Finnish Virutal Univer- } \\
\text { sity }\end{array}$ & ICT for Development & & \\
\hline $\begin{array}{l}\text { George Mason Uni- } \\
\text { versity }\end{array}$ & Managing the Digital Divide & G & School of Public Policy \\
\hline Georgia Tech & $\begin{array}{l}\text { Computing for Social Good/Computing for } \\
\text { Good (C4G) }\end{array}$ & $\mathrm{U} / \mathrm{G}$ & $\begin{array}{l}\text { International Affairs and Com- } \\
\text { puter Science }\end{array}$ \\
\hline Georgia Tech & Science, Technology \& International Affairs & $U$ & $\begin{array}{l}\text { International Affairs and Com- } \\
\text { puter Science }\end{array}$ \\
\hline Georgia Tech & $\begin{array}{l}\text { Computers, Communication \& International } \\
\text { Development }\end{array}$ & G & $\begin{array}{l}\text { International Affairs and Com- } \\
\text { puter Science }\end{array}$ \\
\hline $\begin{array}{l}\text { Global Virtual Univer- } \\
\text { sity }\end{array}$ & ICT in Development & & \\
\hline Indiana University & Globalization and Information & G & School of Informatics \\
\hline IIT Bombay & ICT, Gender and Development & & Psychology \\
\hline IIT Bombay & $\begin{array}{l}\text { Information and Communication Technolo- } \\
\text { gies For Socio-Economic Development }\end{array}$ & & \\
\hline $\begin{array}{l}\text { Indian Institute of } \\
\text { Technology Delhi }\end{array}$ & Electronic Governance & U & Sociology \\
\hline KTH Sweden & Introduction to ICT for Development & & \\
\hline Loyola College (MD) & $\begin{array}{l}\text { Community Informatics/Community Tele- } \\
\text { centers }\end{array}$ & G & Computer Science \\
\hline MIT & $\begin{array}{l}\text { ICT4D: Information and Communication } \\
\text { Technologies for Development }\end{array}$ & & $\begin{array}{l}\text { Health Sciences, Computer } \\
\text { Science }\end{array}$ \\
\hline
\end{tabular}




\begin{tabular}{|c|c|c|c|}
\hline MIT & $\begin{array}{l}\text { Launching Mobile Ventures for the Next } \\
\text { Billion Consumers }\end{array}$ & & $\begin{array}{l}\text { Health Sciences, Computer } \\
\text { Science }\end{array}$ \\
\hline MIT & Dlab II - ICT4D & & $\begin{array}{l}\text { Center for Developmental } \\
\text { Comm. }\end{array}$ \\
\hline $\begin{array}{l}\text { Michigan State Uni- } \\
\text { versity }\end{array}$ & ICT for Development & $U$ & $\begin{array}{l}\text { Department of Telecommunica- } \\
\text { tion }\end{array}$ \\
\hline $\begin{array}{l}\text { Michigan State Uni- } \\
\text { versity }\end{array}$ & ICT Global Corps Field Study & $U$ & $\begin{array}{l}\text { Department of Telecommunica- } \\
\text { tion }\end{array}$ \\
\hline Monash University & Social informatics & G & $\begin{array}{l}\text { Faculty of Information Technol- } \\
\text { ogy }\end{array}$ \\
\hline $\begin{array}{l}\text { MOP Vaishnav Col- } \\
\text { lege for Women }\end{array}$ & Information \& Communication Technologies & G & Communications \\
\hline $\begin{array}{l}\text { National University Of } \\
\text { Singapore }\end{array}$ & State \& Civil Society In The Information Age & & $\begin{array}{l}\text { Communications and New Media } \\
\text { Programme }\end{array}$ \\
\hline $\begin{array}{l}\text { National University Of } \\
\text { Singapore }\end{array}$ & ICTs \& Development & & $\begin{array}{l}\text { Communications and New Media } \\
\text { Programme }\end{array}$ \\
\hline NYU & $\begin{array}{l}\text { Information and Communication Technolo- } \\
\text { gies (ICT) for Developing Regions }\end{array}$ & & Computer Science \\
\hline NYU & $\begin{array}{l}\text { New Approaches to Digital Learning (Educa- } \\
\text { tional Technologies in Global Context) }\end{array}$ & & Educational Communications \\
\hline Örebro University & $\begin{array}{l}\text { Egovernment Systems in Developing Count- } \\
\text { ries }\end{array}$ & G & School of Business \\
\hline Queen's University & $\begin{array}{l}\text { Advanced Studies in Information and Com- } \\
\text { munication Technology }\end{array}$ & $U$ & Sociology \\
\hline $\begin{array}{l}\text { Royal Holloway, Uni- } \\
\text { versity of London }\end{array}$ & $\begin{array}{l}\text { Information and Communication Technolo- } \\
\text { gies for Development }\end{array}$ & $U$ & Geography \\
\hline $\begin{array}{l}\text { Royal Holloway, Uni- } \\
\text { versity of London }\end{array}$ & ICT4D Short Courses & & \\
\hline $\begin{array}{l}\text { Royal Institute of } \\
\text { Technology in Stock- } \\
\text { holm }\end{array}$ & $\begin{array}{l}\text { Doctoral seminar on Social and community } \\
\text { informatics }\end{array}$ & G & \\
\hline SUNY - Albany & Social and Community Informatics & $U$ & $\begin{array}{l}\text { Department of Information Stud- } \\
\text { ies }\end{array}$ \\
\hline Syracuse & Technology as Public Good & G & $\begin{array}{l}\text { Community and Information } \\
\text { Technology Institute }\end{array}$ \\
\hline Teri University (India) & $\begin{array}{l}\text { Science, technology and sustainable devel- } \\
\text { opment }\end{array}$ & G & MDP Program \\
\hline Texas State University & International Communication Issues & G & Journalism \\
\hline Tulane University & $\begin{array}{l}\text { Information Technology and International } \\
\text { Development }\end{array}$ & $U$ & $\begin{array}{l}\text { Payson Center for International } \\
\text { Dev. }\end{array}$ \\
\hline Tulane University & $\begin{array}{l}\text { Information and Communication Technolo- } \\
\text { gies for International Development: Global } \\
\text { Digital Divide }\end{array}$ & G & $\begin{array}{l}\text { Payson Center for International } \\
\text { Dev. }\end{array}$ \\
\hline U Capetown & ICT4D & $U$ & Computer Science \\
\hline U Indiana & Globalization and Information & G & School of Informatics \\
\hline U Michigan & $\begin{array}{l}\text { Digital Government I: Information Technology } \\
\text { and Democratic Politics }\end{array}$ & G & School of Information \\
\hline U Michigan & $\begin{array}{l}\text { Digital Government II: Information Technol- } \\
\text { ogy and Democratic Administration }\end{array}$ & G & School of Information \\
\hline U Michigan & Community Information Corps Seminar & G & School of Information \\
\hline U Michigan & Information Use in Communities & G & School of Information \\
\hline $\begin{array}{l}\text { University of Missouri } \\
\text { St. Louis }\end{array}$ & Development Communication & & \\
\hline
\end{tabular}




\begin{tabular}{|c|c|c|c|}
\hline U Toronto & Community Informatics & G & School of Information \\
\hline U Toronto & Digital Divides & G & School of Information \\
\hline U Wisconsin & $\begin{array}{l}\text { Linking Information Technology and Com- } \\
\text { munity Organization Information Practices }\end{array}$ & $U$ & Sociology \\
\hline UC Berkeley & Social Entrepreneurs in ICTD & & School of Information \\
\hline UC Berkeley & $\begin{array}{l}\text { ICT for Development: Context, Strategies and } \\
\text { Impacts }\end{array}$ & & School of Information \\
\hline UC Berkeley & $\begin{array}{l}\text { Graduate Reading Seminar on ICT and } \\
\text { Development }\end{array}$ & G & School of Information \\
\hline UC Berkeley & $\begin{array}{l}\text { Information and Communications Technology } \\
\text { for Development }\end{array}$ & & School of Information \\
\hline UC Berkeley & User Interface Design and Development & G & School of Information \\
\hline UC Berkeley & Governanace of the E-conomy & $U$ & Political Science \\
\hline UC Berkeley & Designing Rural Computing Applications & G & School of Information \\
\hline UC Berkeley and CMU & $\begin{array}{l}\text { An Information and Communications Tech- } \\
\text { nology (ICT) Framework for Developing } \\
\text { Regions }\end{array}$ & $U$ & \\
\hline UC Santa Cruz & Technology Targeted at Social Issues & & Computer Science \\
\hline UC Santa Cruz & $\begin{array}{l}\text { Information and Computing Technology for } \\
\text { Development }\end{array}$ & & Computer Science \\
\hline $\begin{array}{l}\text { Universidad Católica } \\
\text { Boliviana }\end{array}$ & ICT for Development & & \\
\hline $\begin{array}{l}\text { Universidad Com- } \\
\text { plutense de Madrid }\end{array}$ & $\begin{array}{l}\text { Las Tecnologías de Información y Comuni- } \\
\text { caciones como herramientas de Desarrollo } \\
\text { Humano: Brechas y oportunidades digitales }\end{array}$ & & \\
\hline $\begin{array}{l}\text { Universidad } \\
\text { Politécnica de Madrid }\end{array}$ & TIC y Desarrollo Humano & & \\
\hline University of Brighton & Information and Communications Policy & & \\
\hline University of Brighton & Communications and Development & & \\
\hline University of Brighton & Community Informatics & & \\
\hline University of Brighton & The Network Society & & \\
\hline $\begin{array}{l}\text { University of California } \\
\text { at Los Angeles }\end{array}$ & $\begin{array}{l}\text { Information Services in Diverse Cultural } \\
\text { Communities }\end{array}$ & $U$ & Dept of Information Studies \\
\hline $\begin{array}{l}\text { University of Colorado, } \\
\text { Boulder }\end{array}$ & Graduate Seminar on ICTD & G & ATLAS Institute \\
\hline $\begin{array}{l}\text { University of Colorado, } \\
\text { Boulder }\end{array}$ & ICTD Projects Course & G & ATLAS Institute \\
\hline $\begin{array}{l}\text { University of Colorado, } \\
\text { Boulder }\end{array}$ & Fieldwork Methods for ICTD Practitioners & G & ATLAS Institute \\
\hline University of Exeter & $\begin{array}{l}\text { Building Sustainable Communities: Regen- } \\
\text { eration and Development }\end{array}$ & G & Geography \\
\hline $\begin{array}{l}\text { University of Illinois } \\
\text { (UIUC) }\end{array}$ & $\begin{array}{l}\text { Digital Divide: Policy Research and Com- } \\
\text { munity Empowerment }\end{array}$ & G & Library and Information Science \\
\hline $\begin{array}{l}\text { University of Illinois } \\
\text { (UIUC) }\end{array}$ & Community Informatics Concepts & G & Library and Information Science \\
\hline $\begin{array}{l}\text { University of Illinois } \\
\text { (UIUC) }\end{array}$ & $\begin{array}{l}\text { Community Informatics Research and Theory } \\
1\end{array}$ & G & Library and Information Science \\
\hline
\end{tabular}




\begin{tabular}{|c|c|c|c|}
\hline $\begin{array}{l}\text { University of Illinois } \\
\text { (UIUC) }\end{array}$ & Social informatics & G & Library and Information Science \\
\hline University of Kuopio & $\begin{array}{l}\text { Information and Communication Technology } \\
\text { for Development }\end{array}$ & & \\
\hline $\begin{array}{l}\text { University of Manches- } \\
\text { ter }\end{array}$ & ICTs for Development & G & IDPM \\
\hline $\begin{array}{l}\text { University of Manches- } \\
\text { ter }\end{array}$ & ICTs and Social Economic Development & G & IDPM \\
\hline $\begin{array}{l}\text { University of Manches- } \\
\text { ter }\end{array}$ & E-Government & G & IDPM \\
\hline $\begin{array}{l}\text { University of Manches- } \\
\text { ter }\end{array}$ & ICTs in Practice & G & IDPM \\
\hline $\begin{array}{l}\text { University of Maryland } \\
\text { - Baltimore County }\end{array}$ & Women, Gender and Information Technology & & \\
\hline University of Missouri & $\begin{array}{l}\text { Digital Divide: Race, Class, Education and } \\
\text { Technology }\end{array}$ & G & Law \\
\hline $\begin{array}{l}\text { University of Oslo, } \\
\text { Norway }\end{array}$ & $\begin{array}{l}\text { Implementing Health Information Systems } \\
\text { Programme from Anthropological Perspective }\end{array}$ & G & Department of Informatics \\
\hline University of Oxford & ICT for Development & G & Oxford Internet Institute \\
\hline University of Salzburg & Technologies and Humanities I & & CASRICTS \\
\hline University of Salzburg & Technologies and Humanities II & & CASRICTS \\
\hline University of Salzburg & Politics \& ICTs & & CASRICTS \\
\hline $\begin{array}{l}\text { University of San } \\
\text { Francisco }\end{array}$ & International Telecomm Technology & & $\begin{array}{l}\text { School of Business and Man- } \\
\text { agement }\end{array}$ \\
\hline $\begin{array}{l}\text { University of San } \\
\text { Francisco }\end{array}$ & Telecommunication Policy and Strategy & & $\begin{array}{l}\text { School of Business and Man- } \\
\text { agement }\end{array}$ \\
\hline $\begin{array}{l}\text { University of San } \\
\text { Francisco }\end{array}$ & Special Topics & & $\begin{array}{l}\text { School of Business and Man- } \\
\text { agement }\end{array}$ \\
\hline $\begin{array}{l}\text { University of Southern } \\
\text { California }\end{array}$ & $\begin{array}{l}\text { Research Seminar on Mobile phones, On- } \\
\text { Line Community, and Social Change }\end{array}$ & G & \\
\hline $\begin{array}{l}\text { University of the } \\
\text { Philippines }\end{array}$ & Special Topics - ICTD & $U$ & $\begin{array}{l}\text { Public Administration and Gov- } \\
\text { ernance }\end{array}$ \\
\hline University of Toledo & Community Informatics & $U$ & Sociology \\
\hline University of Trento & $\begin{array}{l}\text { CT4SD: Information and Communication } \\
\text { Technologies for Sustainable Development }\end{array}$ & G & $\begin{array}{l}\text { School of Information and Tele- } \\
\text { communicaiton }\end{array}$ \\
\hline $\begin{array}{l}\text { University of Washing- } \\
\text { ton }\end{array}$ & Digital Games Research for ICTD & & $\begin{array}{l}\text { Technical Communication (Engi- } \\
\text { neering) }\end{array}$ \\
\hline $\begin{array}{l}\text { University of Washing- } \\
\text { ton }\end{array}$ & Capstone Projects for ICTD & $U$ & $\begin{array}{l}\text { Computer Science \& Engineer- } \\
\text { ing }\end{array}$ \\
\hline $\begin{array}{l}\text { University of Washing- } \\
\text { ton }\end{array}$ & Technology for Low-Income Regions & $U$ & $\begin{array}{l}\text { Computer Science \& Engineer- } \\
\text { ing }\end{array}$ \\
\hline $\begin{array}{l}\text { University of Washing- } \\
\text { ton }\end{array}$ & Information in Social Context & G & School of Information \\
\hline $\begin{array}{l}\text { University of Washing- } \\
\text { ton }\end{array}$ & ICTD Seminar & G & $\begin{array}{l}\text { Computer Science \& Engineer- } \\
\text { ing }\end{array}$ \\
\hline $\begin{array}{l}\text { University of Washing- } \\
\text { ton }\end{array}$ & $\begin{array}{l}\text { Mobile/Cloud Applications for Emerging } \\
\text { Regions }\end{array}$ & $\mathrm{U} / \mathrm{G}$ & $\begin{array}{l}\text { Computer Science \& Engineer- } \\
\text { ing }\end{array}$ \\
\hline $\begin{array}{l}\text { University of Washing- } \\
\text { ton }\end{array}$ & ICTD Design Experience & $U$ & $\begin{array}{l}\text { Computer Science \& Engineer- } \\
\text { ing }\end{array}$ \\
\hline $\begin{array}{l}\text { University of Washing- } \\
\text { ton }\end{array}$ & Computing for the Developing World & G & $\begin{array}{l}\text { Computer Science \& Engineer- } \\
\text { ing }\end{array}$ \\
\hline $\begin{array}{l}\text { University of Washing- } \\
\text { ton }\end{array}$ & $\begin{array}{l}\text { International Communication and National } \\
\text { Development }\end{array}$ & & \\
\hline
\end{tabular}




\begin{tabular}{|l|l|l|l|}
\hline $\begin{array}{l}\text { Wageningen Univer- } \\
\text { sity }\end{array}$ & $\begin{array}{l}\text { Technography, Researching Technology and } \\
\text { Development }\end{array}$ & & \\
\hline
\end{tabular}

\section{References}

Collins, D., Morduch, J., Rutherford, S. \& Ruthven, O. (2009). Portfolios of the Poor. How the World's Poor Live on \$2 a Day. Princeton: Princeton University Press.

Gerster, R. \& Zimmerman, S. (2005). Up-scaling pro-poor ICT-policies and practices. Swiss Agency for Development and Cooperation. Retrieved 20 October, 2008 from http://www.choike.org/2009/eng/informes/3010.html\#ICT\%20role\%20in\%20achieving\%20the\%20MDGs

Heeks, R. (2010). ICT-for-Development Research. Size and Growth. Retrieved 9 February, 2010 from http://ict4dblog.wordpress.com

InfoDev. (2006). Improving health, connecting people. The role of ICTs in the health sector of developing countries. Retrieved February, 2010 from http://www.asksource.info/pdf/framework2.pdf

ITU. (2009). The World in 2009. ICT Facts and Figures. Retrieved 14 January, 2010 from http://www.itu.int/ITUD/ict/material/Telecom09 flyer.pdf

\section{About the Authors}

John K. Bennett

Dr. Bennett is the Director of the ATLAS Institute and Archuleta Professor of Computer Science at the University of Colorado at Boulder. From 2002 to 2007, he served as the Associate Dean for Education in the College of Engineering and Applied Science. He joined the CU-Boulder faculty in 2000, after serving on the faculty of Rice University for 11 years. He received his Ph.D. in 1988 from the University of Washington. Bennett's primary research interests are broadly in the area of distributed systems, and more narrowly in distributed information management, distributed robotic macro-sensors, and the use of information and communication technology to positively impact developing communities. He is the past President of the Governing Board of Engineers Without Borders - USA.

S. Revi Sterling

Dr. Sterling is the Faculty Director of ICTD graduate studies at the ATLAS Institute. Her research interests include Community ICT readiness, ICT curriculum development, Gender and ICTD, informed consent in ICTD research, fieldwork methods, value-centric design, and the practical application of ICTD to basic service engineering (BSE) initiatives, working with UN-GAID and other cross-sector ICTD initiatives. She has ongoing fieldwork in East Africa, India, and the Peruvian Amazon. 